\title{
Host Selection of Potomida semirugata (Unionidae: Bivalvia) in Reproduction Strategy
}

\author{
Hülya Şereflişan ${ }^{1}$ (i)
}

Cite this article as: Sereflisan, H. (2021). Host selection of Potomida semirugata (Unionidae: Bivalvia) in reproduction strategy. Aquatic Sciences and Engineering, 36(3), 109-115.

ORCID IDs of the author:

H.Ş. 0000-0002-2510-3714

'Department of Aquaculture, Iskenderun Technical University, Marine Sciences and Technology Faculty, Hatay, Turkey

\section{Submitted:}

29.05.2020

Revision Requested:

04.11 .2020

Last Revision Received:

10.01.2021

Accepted:

18.01.2021

Online Published:

08.04.2021

Correspondence:

Hülya Şereflişan

E-mail:

hulya.sereflisan@iste.edu.t

(c) Copyright 2021 The Author(s)

Available online at

https://dergipark.org.tr/ase

\begin{abstract}
Potomida semirugata, which belongs to the Unionidae family, require a host fish to complete their life cycle. In this study, the host fish preference of this species was investigated. Besides, mussel species and hence the attachment state of larvae on the host fish were also investigated. Five different fish species namely Cyprinus carpio, Oreochromis niloticus, Clarias gariepinus, Anguilla anguilla, and Carasobarbus luteus were used as host candidates. In this study, five glass aquaria each containing 140 liters of water without any substrate were used and 3 mussels and 10 fish were placed in each aquarium. The aquaria were monitored for 120 days and the glochidia release on the fish was determined by examining gill tissue, dorsal and caudal fins by using a stereomicroscope. Results indicated that C. carpio and O. niloticus were more preferable in terms of mussel-host fish relationship. The best host fish was determined as C. carpio in terms of gill-fullness and juvenile mussel transformation at the ground of the aquarium. These observations provide significant insight and information regarding the effective culture of freshwater mussels.
\end{abstract}

Keywords: Freshwater bivalve, host fish, P. semirugata, glochidia, Unionidae

\section{INTRODUCTION}

Freshwater mussels (Unionidae), which are important components of the aquatic ecosystems, are among the most threatened animal groups on the planet (Lopes-Lima et al., 2017; 2018). The life cycle of unionids is characterized by a unique obligatory period of larval parasitism on a fish host (Haag, 2012). The glochidium process is defined as a parasitic stage in the life cycle of freshwater bivalve (Unionoidae) molluscs (Kat, 1984; O'Connell \& Neves, 1999; Wachtler et al., 2001; Treasurer \& Turnbull, 2000; Treasurer et al., 2006). Therefore, the fate of glochidia is highly dependent on the presence of a suitable host fish (Barnhart et al., 2008). Lasmigona subviridis, which belongs to the family of Unionidae, can complete its life cycle without the existance of a host (Lellis \& King, 1998). Glochidia complete the embryonic development process in the parts of the female mussel gills called marsupial and then are released from the parent and connect to a host fish (Schwartz \& Dimock, 2001). Potamida live a parasitic stage at the skin, gill and fin of host fish (Meyers \& Millemann, 1977; Haag \& Warren, 2003). Morphologically, glochidia can be rectangular, circular and axe head shaped and are divided into two as with or without a hook (Graf \& Cummings, 2006; Şereflişan et al., 2009; Wen et al., 2018). The glochidia are encapsulated in a cyst, which they form on the epithelial and connective tissue of the host fish after attachment. When they connect to a non-suitable type of fish species, the cyst they produce is deformed and releases the glochidia from the epithelial and/or connective tissue of the fish within a few days (Kat, 1984; Nezlin et al., 1994; Kirk \& Layzer, 1997; Wachtler et al., 2001; Rogers-Lowery \& Dimock, 2003). The host fish is an obligate nutrient source for glochidia (Araujo \& Ramos, 1998; Araujo et al., 2002). The attach- 
ment of glochidia also affects the respiratory performance of the host fish (Thomas et al., 2010). The time spent on the host fish varies from a couple of days to a couple of weeks depending on the host species. Glochidia undergoing metamorphosis leave the host fish and start a new life at the sediment (Fisher \& Dimock, 2002; Jones \& Neves, 2002). As a result of several biological and anthropogenic factors, extinction of freshwater mussels was predicted (Lyons et al., 2007; Zieritz et al., 2012). Causes, such as a long-life time, the long time required to reach sexual maturity, sedentary lifestyles and high glochidia mortality rates, make the mussels vulnerable and difficult to spread (Gatenby et al., 2000). In addition to all these problems, the search for host fish suitable for the glochidia of the mussel species also complicates the continuity of the life cycle (O' Connell \& Neves, 1999). Due to the drying out of wetlands and mass agricultural activities, P. semirugata distribution has decreased in most of Turkey's southern rivers and lakes (Seddon et al., 2014). P. semirugata has a spawning activity in June in Gölbaşı Lake or the southern parts of Turkey (Şereflişan et al., 2013). Possible host fish populations for $P$. semirugata are in danger of decreasing due to intense fishing activities in Gölbaşı Lake. This situation threatens mussel life (Şereflişan, 2014). Since there are decreases in Potomida populations, P. littoralis has recently been listed as Endangered in the IUCN Red List. Therefore, priority protection areas should be created for Potomida species (Seddon et al., 2014).

The aim of this study is to determine the suitable host fish species for P. semirugata in Gölbaşı Lake in the province of Hatay. We believe that the results of this study will provide valuable information for the determination of the status of this freshwater ecosystem and the culture of this potentially threatened mussel species.

\section{MATERIALS AND METHODS}

\section{Mussel collection}

Mussels were collected from Gölbaşı Lake (36 30' 16" N; 36 29' $42^{\prime \prime}$ E) with a surface area of 12,000 acres, which is located in the Kırıkhan district of Hatay, Turkey (Fig 1). Twenty taxa belonging to 9 families, namely Anguillidae, Bagridae, Chiclidae, Cobitidae, Cyprinidae, Cyrinodontidae, Mugilidae, and Poecilidae, have been identified in Lake Gölbaşı (Şereflişan and Şereflişan, 2001). Among these, C. carpio, O. niloticus, C. gariepinus, A. anguilla, and $C$. luteus are the most abundant species in the lake. These fish species were preferred in this study, since the relationship of them with mussels has previously been investigated in a preliminary study. Mussels were randomly collected from the shallow muddy or sandy areas of the lake with scoops and hand rakes of various sizes and by SCUBA diving from the deeper (1-6 m) parts of the lake in early March 2014.

\section{Reproduction monitoring stage}

Collected mussels were transferred to a laboratory in water containers. Before starting the study, mussel samples were kept in an aquarium supplied with tap water for two days so that they can adapt to laboratory conditions. The gender of the mussels was determined by controling its gill glochidia fullness and only female ones were selected. The length, width, height and live weight of female mussels were measured as $6.18 \pm 0.37 \mathrm{~cm}, 4.13 \pm 0.23 \mathrm{~cm}, 2.81 \pm 0.20 \mathrm{~cm}$ and 35.08 $\pm 7.10 \mathrm{~g}$, respectively. During this resting period, it was observed that the valves of the mussels were opened upto $8 \mathrm{~mm}$, since the adductor muscles were loosend because of the lack of stress factors. Five (glass) aquaria of 140 liters $(35 \mathrm{~cm} \times 20 \mathrm{~cm} \times 20 \mathrm{~cm})$ capacity supplied with $22-26{ }^{\circ} \mathrm{C}$ freshwater and continious aeration were prepared without any substrates in the bottom. Three mussels ( $P$. semirugata) and 10 fish samples were placed in each aquarium [A: (C. carpio - P. semirugata), B: (O. niloticus - $P$. semirugata) $C$ : (A. anguilla - $P$. semirugata), D: (C. gariepinus - P. semirugata) E: (C. luteus - $P$. semirugata)]. While the fishes were fed with standard pellet feed, the mussels were fed with a suspended fito-zooplankton mixture containing (Compylodiscus clypeus, Pediastrum bonyanum, Keratella cochlearis, Filinia erminali, Brachionus angularis, Lepadella ovalis, Keratella cochlearis). Glochidia release from the gill and fin of fish was controlled by eye at 2 days intervals. Water discharged from the aquaria was filtered by a $120 \mu \mathrm{m}$ sieve and the waste product was examined under a light microscope (Olympus CX 41). Detected glochidias were visualized by scanning electron microscope (SEM). The samples were then dehydrated in an ethanol series of $60 \%, 70 \%$, and $80 \%$ for 30 min in each. The samples were mounted on stubs with conductive double-sided carbon tape and coated with gold/palladium in a sputter coater (Polaron SC7620, UK) for $90 \mathrm{sec}$ at $9 \mathrm{~mA}$. The samples were examined and photographed using a JEOL JSM 5500 scanning electron microscope (SEM) at an accelerating voltage of 5 kV. (Şereflişan et al., 2009).

\section{Statistical analysis}

The t-test, which is used to compare the means of two independent groups, was used.

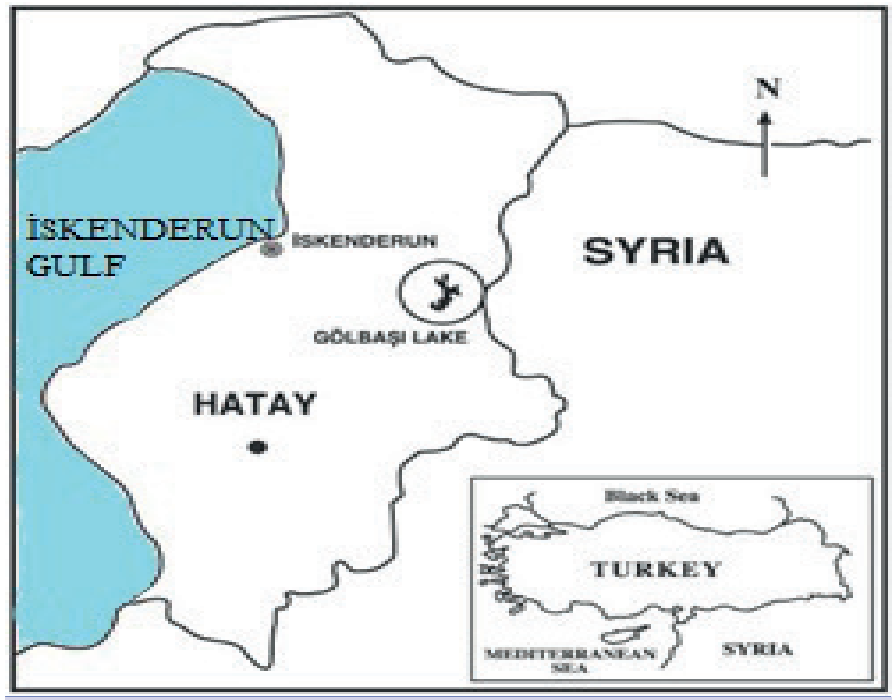

Figure 1. Map of the study area (Gölbaşı Lake)

\section{RESULTS}

\section{Reproduction strategy of $P$. semirugata} Aquarium A (Relationship between $C$. carpio and $P$. semirugata) In the first week of May, mussel shell opening and glochidia release were frequently observed. When the gills of $C$. carpio were examined, denser glochidia were examined in the gill lamellae. Aquarium water has a higher turbidity with a more suspended view. There were glochidia detected in the dorsal and caudal fin 
of the fish. The glochidia released occured twice and 25 days after the last release, juvenile mussels were detected in the bottom of the aquarium. A third release occured in the first week of June (with a water temperature of $26^{\circ} \mathrm{C}$ ) Glochidium detected in the fish gill was determined to be on average 140-170 $\mu \mathrm{m}$ in size. At the bottom of the aquarium, juvenile mussels were detected in the size of $180-200 \mu \mathrm{m}$ (Table 1). As a result, C.carpio was found as a suitable host for $P$. semirugata (Fig 2. A).

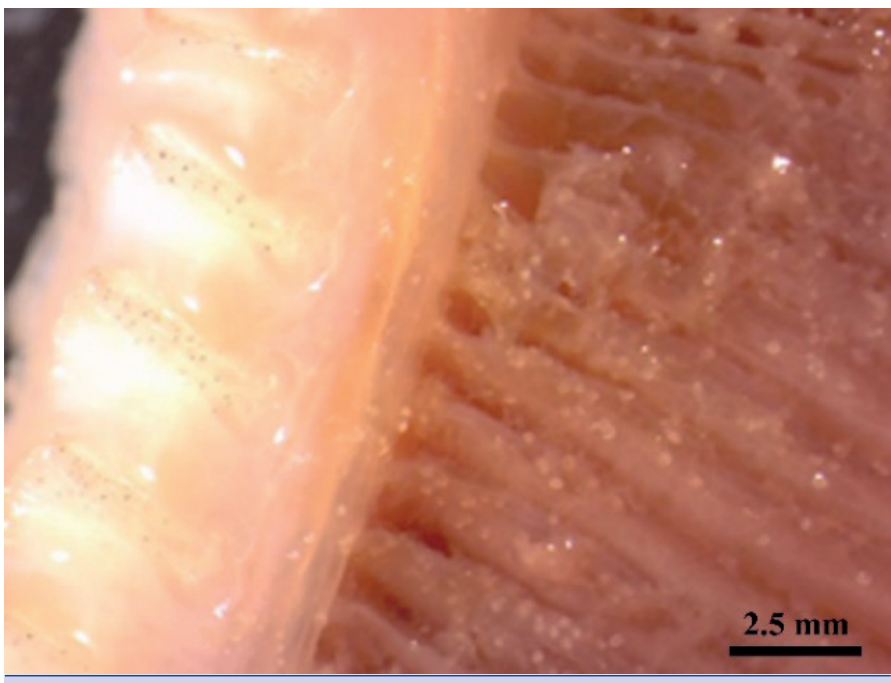

Figure 2A. P. semirugata glochidia attached to the gill filaments of C. carpio.

\section{Aquarium B (Relationship between $O$. niloticus and $P$. semirugata)} Glochidia release was first observed in the second week of April. Even though less dense glochia were observed in the gill of $O$. niloticus than the gill of $C$. carpio, a denser glochidia population was found in the aquarium bottom. The aquarium water was slightly suspended and turbid. Shells of $P$. semirugata were usually closed; they were rarely opened. Release occured twice at intervals (Fig 2.B). The third release was observed in the second week of May and juveniles of $P$. semirugata were observed

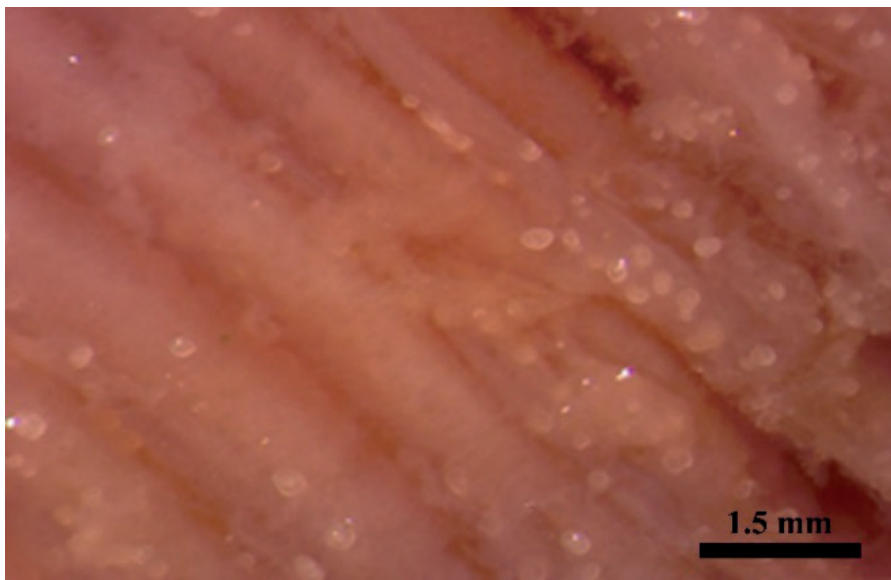

Figure 2B. P. semirugata glochidia attached to the gill filaments of $O$. niloticus. at the aquarium bottom. Glochidium detected in the fish gill was determined to be on average 120-160 $\mu \mathrm{m}$ in size. At the bottom of the aquarium, juvenile mussels were detected in the size of 150-190 $\mu \mathrm{m}$. (Table 1). These results confirm the preferance of O.niloticus as host.

\section{Aquarium C (Relationship between $A$. anguilla and $P$. semirugata)} Starting from the first week of April, mussels were monitored continuoulsy and no changes were observed in the openings of shells until the first of May. When the waste obtained from the bottom siphon of the aquarium was examined, it was found that most of the glochidia packs were in a non-dispersed state. $P$. semirugata did not shape the mantle tissue to attract $A$. anguilla. When the fish's back and tail fin were examined with a stereomicroscope, there were no glochidia detected (Fig 2.C). Even though, glochidia was released four times in P. semirugata, A. anguilla was found to be an unsuitable host.

Table 1. Length measurements $(\mu \mathrm{m})$ of glochidium detected in the gill and the bottom of the aquarium of fish chosen as host by $P$. semirugata (Mean Length $\pm \mathrm{SD}$ )

\begin{tabular}{|c|c|c|c|c|}
\hline \multirow[b]{2}{*}{ Glochidium } & \multicolumn{2}{|c|}{ C. Carpio } & \multicolumn{2}{|c|}{ O. niloticus } \\
\hline & $\begin{array}{c}\text { Mean } \\
\text { Length } \\
\pm \mathrm{SD}(\mu \mathrm{m})\end{array}$ & $\begin{array}{l}\min - \\
\max . \\
(\mu \mathrm{m})\end{array}$ & $\begin{array}{l}\text { Mean } \\
\text { Length } \\
\pm S D \\
(\mu \mathrm{m})\end{array}$ & $\begin{array}{l}\min - \\
\max . \\
(\mu \mathrm{m})\end{array}$ \\
\hline $\begin{array}{l}\text { Glochidium } \\
\text { size in the } \\
\text { fish gill }\end{array}$ & $\begin{array}{l}162 \pm \\
0.45^{a}\end{array}$ & $140-170$ & $\begin{array}{c}145 \\
\pm 0.38^{b}\end{array}$ & $120-160$ \\
\hline $\begin{array}{l}\text { Sizes of } \\
\text { glochidium } \\
\text { detected in } \\
\text { the aquarium }\end{array}$ & $190 \pm 0.22^{a}$ & $180-200$ & $70 \pm 0.31^{b}$ & $150-190$ \\
\hline
\end{tabular}

* Mean values with different superscript on the same row are significantly different $(p<0.05)$.

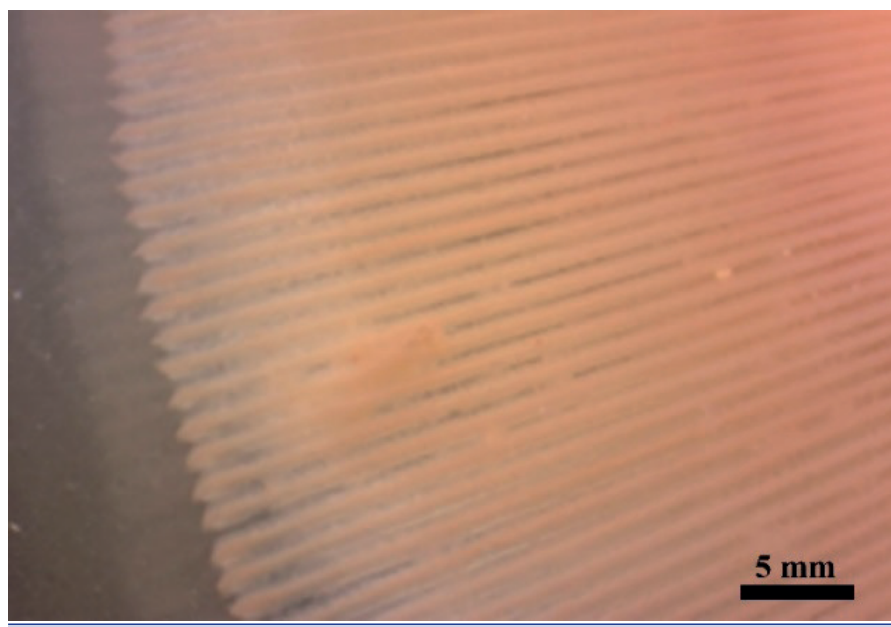

Figure 2C. Gill filaments of $A$. anguilla free from glochidia. 


\section{Aquarium D (Relationship between C. gariepinus and $P$. semirugata)}

When the bottom of the aquarium was examined in the second week of May, glochidia release was observed. However, glochidia were not on the gills and dorsal and caudal fins of C. gariepinus (Fig 2.D). It was observed that the aquarium water was clear and the mussel shells were closed. Glochidia release occurred three times by the end of May, however, it was understood that C. gariepinus was not a suitable host for $P$. semirugata.

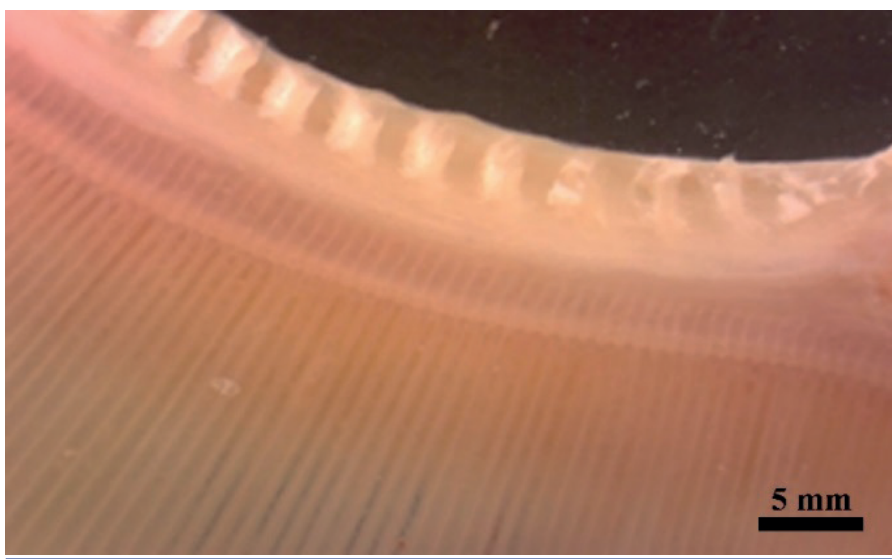

Figure 2D. Gill filaments of C. gariepinus free from glochidia.

Aquarium E (Relationship between $C$. luteus and $P$. semirugata) Glochidia release was observed twice at the third and fourth week of May. Results showed that C. Luteus were not preferred as a host by $P$. semirugata since there were no glochidia observed at the gills as well as on the dorsal and caudal fins (Fig 2.E). It is worth mentioning that glochidia packets were found scattered rather than whole at the aquarium bottom.

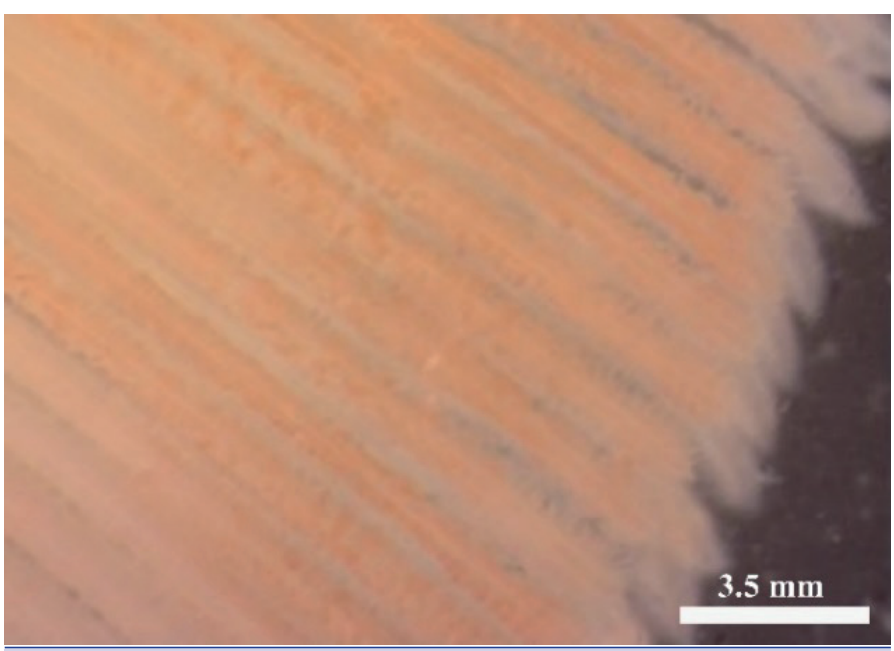

Figure 2E. Gill filaments of C. luteus free from glochidia.

Unlike many other members of Unionidae, no hooks were found at the front end of the dorsal and ventral shell of $P$. semirugata larvae (Fig 3.A; 3.B; 3.C; 3.D) and 3-4 rows of protruding structures were observed in this region (Fig 4.A; 4.B; Fig 5).

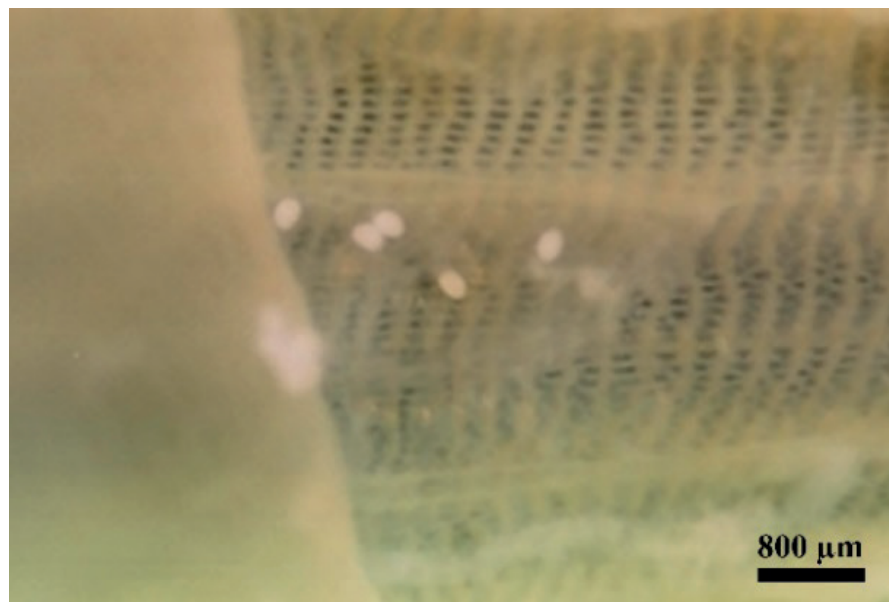

Figure 3A. The preglochidia in the marsupial region of $P$. semirugata gill.

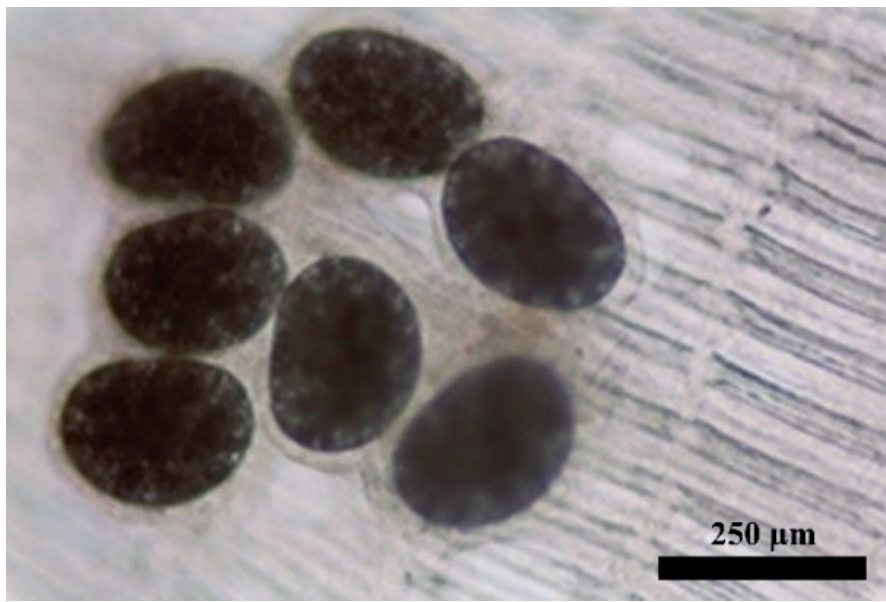

Figure 3B. Preglochidia group in the marsupial region of the gill of $P$. semirugata.

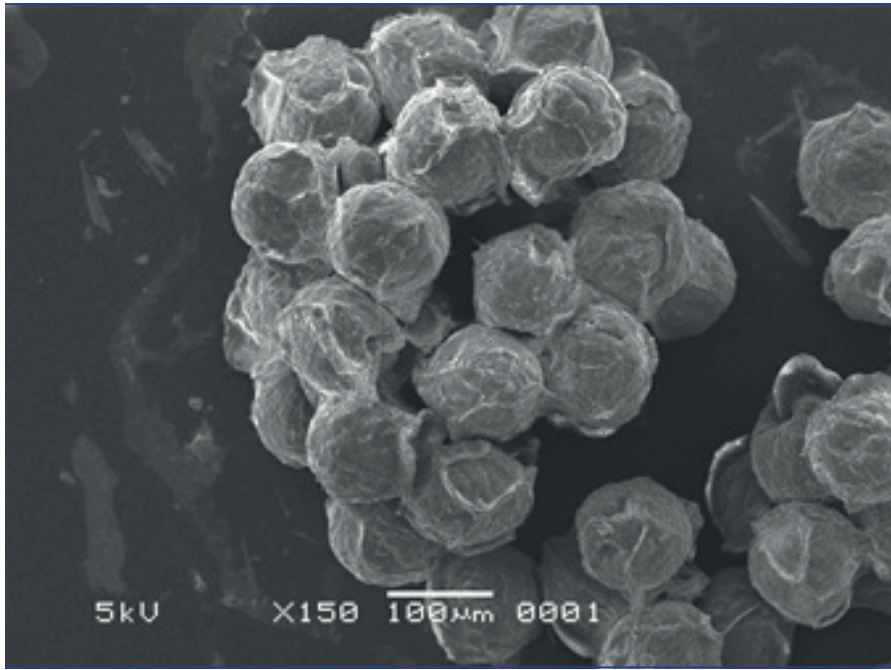

Figure 3C. Preglochidia, which were fertilized in the gonad of $P$. semirugata. 


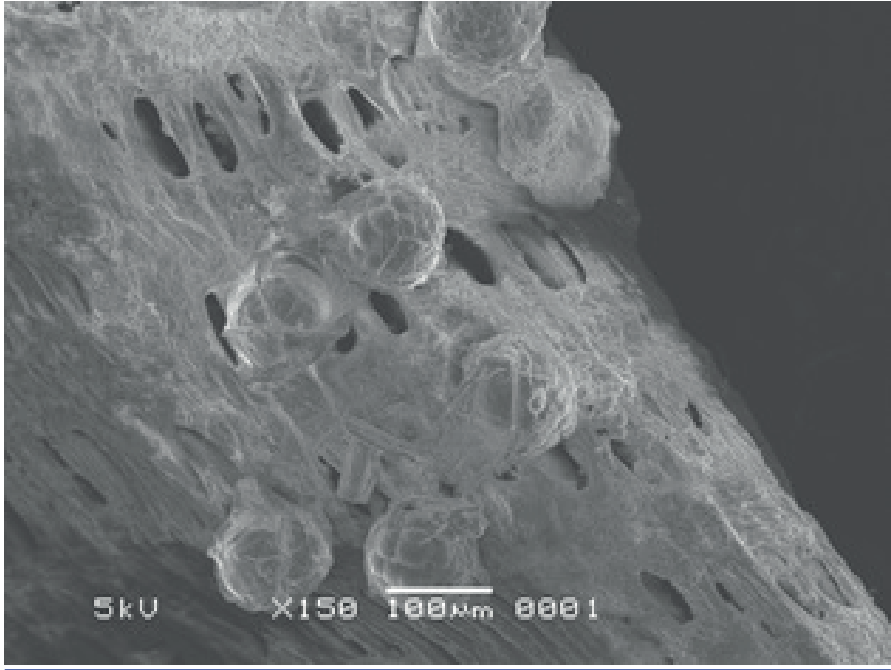

Figure 3D. SEM image of preglochidia in the gill of $P$. semirugata.

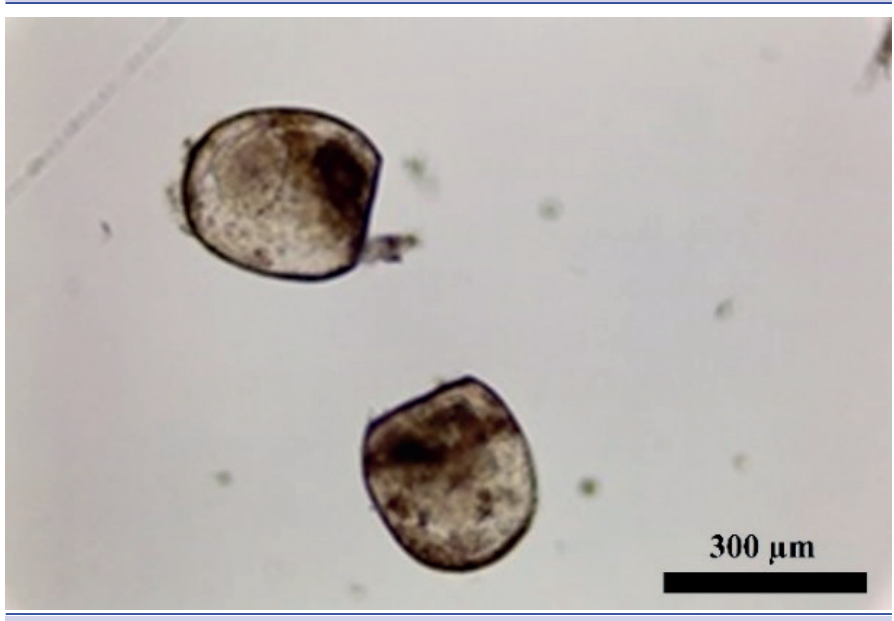

Figure 4A. Image of $P$. semirugata juveniles separated from the host fish (under a stereo microscope).

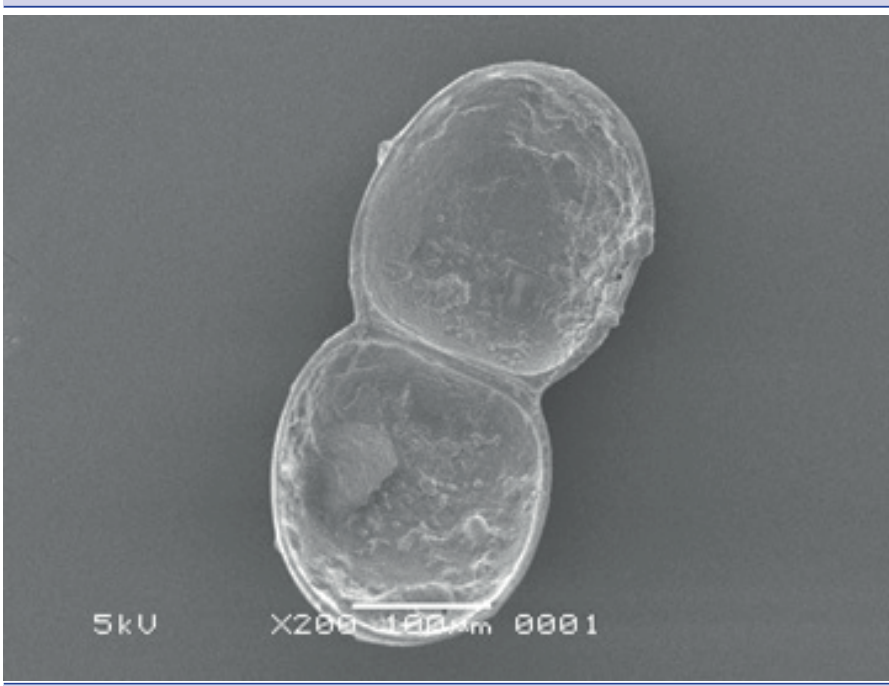

Figure 4B. SEM image of $P$. semirugata juveniles separated from the host fish.

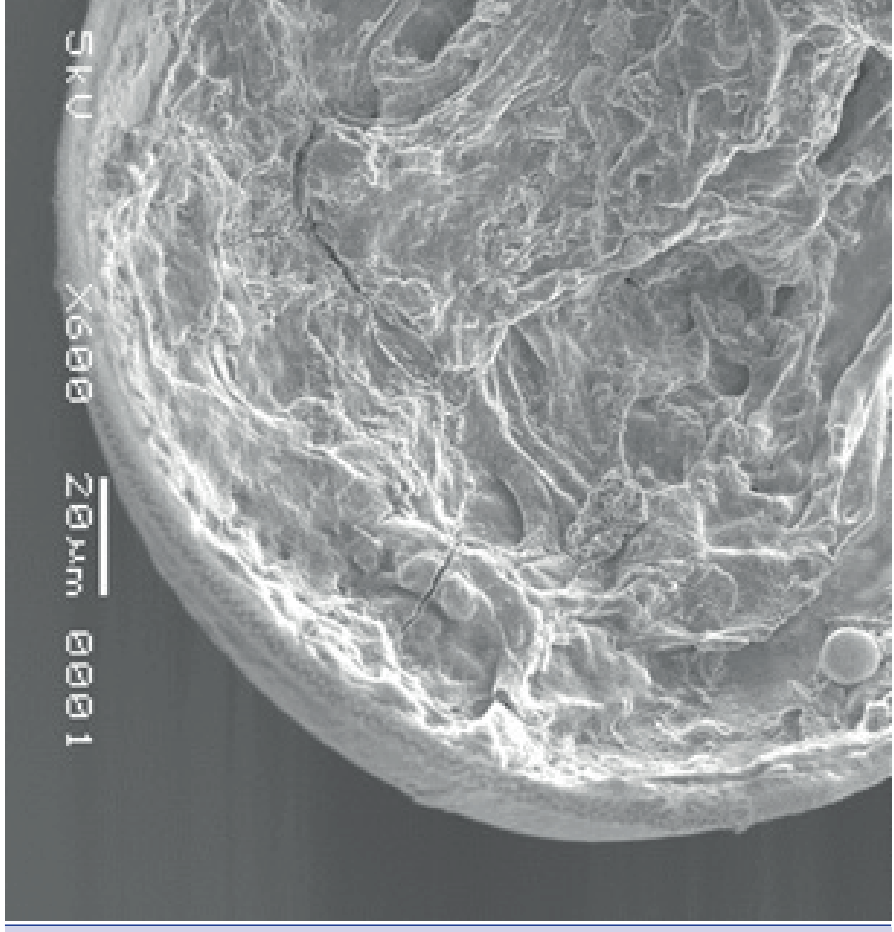

Figure 5. SEM image of ventral valve of $P$. semirugata without hooks.

\section{DISCUSSION}

Host fish, and the members of various fish families such as Centrarchidae, Cyprinidae, Percidae, Ictaluridae, Cottidae and Sciaenidae etc. were prefered as a host by various mussel species (Haag et al., 1999; O’Dee \& Watters, 2000; Haag \& Warren, 2003; Şereflişan et al., 2009; Haag, 2010; Şereflişan, 2018; Modesto et al., 2018; Lopes-Lima et al., 2020); whereas, Unionid mussels prefer fishes which belong to the Cyprinidae family (Haag et al., 1999; Haag \& Warren, 2003; O'Dee \& Watters, 2000; Larsson, 2015). There are some studies that report Margaritifera margaritifera, Unio crassus and Unio terminalis prefer Salmo trutta, Alburnus alburnus and $C y$ prinus carpio as a host for glachidia release, respectively (Poulin, 2000; Thomas et al., 2010; Şereflişan, 2018). Similarly, P. semirugata samples examined in this study preferred the members of Cyprinidae and Cichlidae families as host.

The importance of glochidia release to find suitable host fish in freshwater mussels has been reported (Riusech \& Barnhart, 2000). These toothed or toothless hook structures are the most important structure of mussel larvae since they help them to connect to the gill or fins of host fish. Glochidia with a hook are attached to the skin and gills of the host fish while the ones without a hook are usually found encapsulated among the gill filaments of the host (Barnhart et al., 2008). On the other hand, the ones which do not have hook structure are usually encapsulated inside the gills of host fish (Wachtler et al., 2001). Similarly, in this study, hookless glochidia of $P$. semirugata were only detected at the gills of host fish.

Hookless glochidia have been observed in the Unionoidae including Potomida (Graf \& Cummings, 2006). Glochidia of P. 
semirugata have a large number of protrusions with 4 to 5 rows without hooks inside the anterior part of the dorsal and ventral of the two shells (Giusti, 1973; Şereflişan et al., 2009). Approximately 6 hours after release of hookless glochidials by the mussel to the appropriate host, the glochidia are encapsulated by the epithelial tissue of the fish and a cyst is formed (Rogers-Lowery \& Dimock, 2006). When glochidia produced a cyst on an unsuitable host fish, it was rejected by the immune system and the glochidia died (Wachtler et al., 2001; Rogers-Lowery \& Dimock, 2003). In this study, 5-9 hours after glochidia release, cyct formation as a result of encapsulation of glochidia in the gill tissue was detected. Previous studies reported that anti-glochidial factors are found in the serum of fish infected with glochidia and dead glochidials are poured from the fish gills (Meyers et al., 1980; Waller \& Mitchell, 1989; Kirk \& Layzer, 1997; O'Connell \& Neves, 1999). Despite no studies having been conducted on the fish serum, the attachment of $P$. semirugata glochidia on $C$. carpio and O. niloticus may be due to lack of these anti-glochidia factors in these hosts. In this study, Glochidia were found only in C. carpio and $O$. niloticus gills on the $2^{\text {nd }}, 4^{\text {th }}, 6^{\text {th }}$, and $8^{\text {th }}$ days after $P$. semirugata glochidia release. Others were rejected by the host on the $2^{\text {nd }}$ and $4^{\text {th }}$ day. Especially, in the $A$. anguilla aquarium, glochidia packets were detected undisturbed which indicates that glochidia did not prefer A. anguilla as the host. Some mussels use mantle tissue to lure fish in the glochidia release (Barnhart \& Roberts, 1995; Haag \& Varren, 2003). In this study, P.semirugata did not alter its mantle tissue; it only kept its shells 3-4 mm open during glochidia release.

Fertilized eggs in female mussels produce larvae called glochidium and are kept in the marsupial pockets of the gills ready to be released to the host fish (Lang, 1998; von Proschwitz, 1999; Şereflişan, 2009).

\section{CONCLUSIONS}

In this study $P$. semirugata collected from Gölbaşı Lake in the province of Hatay was investigated in terms of host preferences using five different fish species. Also, hookless glochidia of P.semirugata were examined by SEM to understand their binding strategy to the fish gill. Results provided in this study provide significant insight and information regarding host selection in freshwater mussel production when their presence in the ecological chain gets under a threat. With this study, determining the fish preferred by $P$. semirugata as a host, the prey pressure will be reduced and the mussel-host fish relationship will be preserved. In this study, preferable fish host species were determined but the host selection criteria of $P$. semirugata is still worth exploring ( $\mathrm{Zi}$ uganov \& Nezlin, 1988; Bauer \& Wachtler, 2001; Geist, 2010; Şereflişan, 2018).

Ethics committee approval: Ethics committee approval was not required.

Conflict of Interests: There are no conflicts of interest to declare.

Acknowledgement: The author would like to thank Menderes Şereflişan for his assistance with the collection of the mussels and Ece Kılıç for her English language corrections.
Author contribution: $\mathrm{H}$. Şereflişan designed the study, collected the mussels, planned and performed all the procedures and drafted the manuscript. The author interpreted the results, edited the manuscript and accepted its final version.

\section{Disclosure: -}

\section{REFERENCES}

Araujo, R., Ramos, M.A. (1998). Description of the glochidium of Margaritifera auricularia (Spengler 1793)(Bivalvia, Unionoidea). Philosophical Transactions of the Royal Society of London. Series B: Biological Sciences, 353: 1553-1559. [CrossRef]

Araujo, R., Cámara, N., Ramos, M.A. (2002). Glochidium metamorphosis in the endangered freshwater mussel Margaritifera auricularia (Spengler, 1793): a histological and scanning electron microscopy study. Journal of Morphology, 254: 259-265. [CrossRef]

Barnhart, M. C., Roberts, A.D. (1995). Reproduction and fish hosts of unionids from the Ozark Uplifts. In Conservation and management of freshwater mussels II. Proceedings of a UMRCC Symposium 16: 18.

Barnhart, M.C., Haag, W.R., Roston, W.N. (2008). Adaptations to host infection and larval parasitism in Unionoida. Journal of the North American Benthological Society, 27: 370-394. [CrossRef]

Bauer, G., Wächtler, K. (2001). Environmental relationships of naiads: threats, impact on the ecosystem, indicator function. In Ecology and evolution of the freshwater mussels Unionoida Springer, Berlin, Heidelberg pp. 311-315. [CrossRef]

Fisher, G. R. Dimock, J.R.V. (2002). Ultrastructure of the mushroom body: digestion during metamorphosis of Utterbackia imbecillis (Bivalvia: Unionidae). Invertebrate Biology, 121: 126-135. [CrossRef]

Gatenby, C.M., Morrison, P. A. Neves, R.J., Parker, B.C. (2000). A protocol for the salvage and quarantine of unionid mussels from zebra musselinfested waters. In: Freshwater Mollusk Symposia Proceedings, (R. A. Tankersley, D. I. Warmolts, G. T. Watters, B. J. Armitage, P. D. Johnson, and R. S. Butler, eds), 9-18. Ohio Biological Survey, Columbus, Ohio.

Geist, J. (2010). Strategies for the conservation of endangered freshwater pearl mussels (Margaritifera margaritifera L.): a synthesis of conservation genetics and ecology. Hydrobiologia, 644: 69-88. [CrossRef]

Giusti, F. (1973). The minute shell structure of the glochidium of some species of the genera Unio, Potomida and Anodonta (Bivalvia, Unionacea). Malacologia, 14: 1-30.

Graf, D.L. Cummings, K.S. (2006). Palaeoheterodont diversity (Mollusca: Trigonioida+ Unionoida): what we know and what we wish we knew about freshwater mussel evolution. Zoological Journal of the Linnean Society, 148: 343-394. [CrossRef]

Haag, W.R., Warren, M.L., Shillingsford, M. (1999). Host fishes and hostattracting behavior of Lampsilis altilis and Villosa vibex (Bivalvia: Unionidae). The American Midland Naturalist, 141: 149-158. [CrossRef]

Haag, W.R., Warren, J.M.L. (2003). Host fishes and infection strategies of freshwater mussels in large Mobile Basin streams, USA. Journal of the North American Benthological Society, 22: 78-91. [CrossRef]

Haag, W.R. (2010). A hierarchical classification of freshwater mussel diversity in North America. Journal of Biogeography, 37: 12-26. [CrossRef]

Haag, W.R. (2012). North American Freshwater Mussels: Natural History, Ecology, and Conservation. Cambridge University Press, Cambridge. [CrossRef]

Jones, J.W., Neves, R.J. (2002). Life history and propagation of the endangered fanshell pearl mussel, Cyprogenia stegaria Rafinesque (Bivalvia: Unionidae). Journal of the North American Benthological Society, 21: 76-88. [CrossRef]

Kat, P.W. (1984). Parasitism and the Unionacea (bivalvia). Biological Reviews, 59: 189-207. [CrossRef] 
Kirk, S. G., Layzer, J.B. (1997). Induced metamorphosis of freshwater mussel glochidia on nonhost fish. Nautilus-Paper Edition 110: 102.

Lang, K. (1998). Die Bachmuschel Unio crassus (Philipsson, 1788) im Niederbach: Bestandssituation, Fortpflanzungsbiologie und Wanderverhalten. Dipl.-Arb. Univ. Freiburg.

Larsson, M. (2015). Interaction between fish and freshwater mussels. Degree project for Master of Science in Biology Animal Ecology, 45 hec, ht 2015 Department of Biological and Environmental Sciences University of Gothenburg.

Lellis, W.A., King, T.L. (1998). Release of metamorphosed juveniles by the green floater, Lasmigona subviridis. US Fish and Wildlife Service, 16: 23-23.

Lopes-Lima, M., Sousa, R., Geist, J., Aldridge, D.C., Araujo, R., Bergengren, J., Bespalaya, Y., Bódis, E., Burlakova, L., van Damme, D., Douda, K., Froufe, E., Georgiev, D., Gumpinger, C., Karatayev, A., Kebapçı, Ü., Killeen, I., Lajtner, J., Larsen, B.M., Lauceri, R., Legakis, A., Lois, S., Lundberg, S., Moorkens, E., Motte, G., Nagel, K.-O., Ondina, P., Outeiro, A., Paunovic, M., Prié, V., von Proschwitz, T., Riccardi, N., RudzĪte, M., Rudzīitis, M., Scheder, C., Seddon, M., Şereflişan, H., Simić, V., Sokolova, S., Stoeckl, K., Taskinen, J., Teixeira, A., Thielen, F., Trichkova, T., Varandas, S., Vicentini, H., Zajac, K., Zajac, T., Zogaris, S. (2017). Conservation status of freshwater mussels in Europe: state of the art and future challenges. Biological Reviews, 92: 572-607. [CrossRef]

Lopes-Lima, M., Burlakova, L.E., Karatayev, A.Y., Mehler, K. Seddon, M., Sousa, R. (2018). Conservation of freshwater bivalves at the global scale: diversity, threats and research needs. Hydrobiologia, 810: 1-14. [CrossRef]

Lopes-Lima, M., Hinzmann, M., Varandas, S., Froufe, E., Reise, J., Moreira, C., Araújo, S., Miranda, F., Gonçalves, D.V., Beja, P., Sousa, R., Teixeira, A. (2020). Setting the stage for new ecological indicator species: A holistic case study on the Iberian dolphin freshwater mussel Unio delphinus Spengler, 1793. Ecological Indicators, 111:105987 [CrossRef]

Lyons, M.S., Krebs, R.A., Holt, J.P., Rundo, L.J., Zawiski, W. (2007). Assessing causes of change in the freshwater mussels (Bivalvia: Unionidae) in the Black River, Ohio. The American Midland Naturalist, 158: 1-16. [CrossRef]

Meyers, T.R., Millemann, R.E. (1977). Glochidiosis of salmonid fishes. I. Comparative susceptibility to experimental infection with Margaritifera margaritifera (L.)(Pelecypoda: Margaritanidae). The Journal of Parasitology, 2:728-733. [CrossRef]

Meyers, T.R., Millemann, R.E., Fustish, C.A. (1980). Glochidiosis of salmonid fishes. IV. Humoral and tissue responses of Coho and Chinook salmon to experimental infection with Margaritifera margaritifera (L.) (Pelecypoda: Margaritiferidae). The Journal of Parasitology, 66: 274-281. [CrossRef]

Modesto, V., Ilarri, M., Souza, A.T., Lopes-Lima, M., Douda, K., Clavero, M., Sousa, R. (2018). Fish and mussels: importance of fish for freshwater mussel conservation. Fish Fish. 19, 244-259. [CrossRef]

Nezlin, L.P., Cunjak, R.A., Zotin, A.A., Ziuganov, V.V. (1994). Glochidium morphology of the freshwater pearl mussel (Margaritifera margaritifera) and glochidiosis of Atlantic salmon (Salmo salar): a study by scanning electron microscopy. Canadian Journal of Zoology, 72: 15-21. [CrossRef]

O'Connell, M.T., Neves, R.J. (1999). Evidence of immunological responses by a host fish (Ambloplites rupestris) and two non-host fishes (Cyprinus carpio and Carassius auratus) to glochidia of a freshwater mussel (Villosa iris). Journal of Freshwater Ecology, 14: 71-78. [CrossRef]

O'Dee, S.H., Watters, G.T. (2000). New or confirmed host identifications for ten freshwater mussels. In Freshwater mollusk symposia proceedings. part I. Proceedings of the conservation, captive care and propagation of freshwater mussels symposium. Ohio Biological Survey Special Publication (pp. 77-82).

Poulin, R. (2000). Variation in the intraspecific relationship between fish length and intensity of parasitic infection: biological and statistical causes. Journal of Fish Biology, 56: 123-137. [CrossRef]
Riusech, F.A., Barnhart, M.C. (2000). Host suitability and utilization in Venustaconcha ellipsiformis and Venustaconcha pleasii (Bivalvia: Unionidae) from the Ozark Plateaus. In Freshwater mollusk symposia proceedings. Ohio Biological Survey Special Publication (pp. 83-91). Columbus, Ohio.

Rogers-Lowery, C.L., Dimock, J.R.V. (2003). Acquired resistance of bluegill sunfish Lepomis macrochirus to glochidia larvae of the freshwater mussel Utterbackia imbecillis (Bivalvia: Unionidae) after multiple infections. Journal of Parasitology, 89: 51-57. [CrossRef]

Rogers-Lowery, C.L., Dimock J.R.V. (2006). Encapsulation of attached ectoparasitic glochidia larvae of freshwater mussels by epithelial tissue on fins of naive and resistant host fish. The Biological Bulletin, 210: 51-63. [CrossRef]

Seddon, M.B., Kebapçı, Ü., Lopes-Lima, U.M., van Damme, D., Smith, K.G. (2014). Freshwater mollusks. In: Smith, K.G., Barrios, V., Darwall, W.R.T., Numa, C. (Eds.) The Status and Distribution of Freshwater Biodiversity in the Eastern Mediterranean (pp. 43-56). Cambridge, UK, Malaga, Spain and Gland, Switzerland.

Schwartz, M.L., Dimock, J.R.V. (2001). Ultrastructural evidence for nutritional exchange between brooding unionid mussels and their glochidia larvae. Invertebrate Biology, 120: 227-236. [CrossRef]

Şereflişan, H. (2014). Gölbaşı Gölü'nde (Hatay) bulunan tatlı su midyelerinin (Unionidae) çevresel koşullarının belirlenmesi. Yunus Araştırma Bülteni, (4): 29-36. [CrossRef]

Şereflişan, H. (2018). Determination of host Fish Suitability for Unio terminalis delicatus (Bivalvia: Unionidae) from Gölbaşı Lake in Turkey. Journal of Advances in VetBio Science and Techniques, 3: 15-22. [CrossRef]

Şereflişan, H., Çek, Ş., Şereflişan, M. (2013). The reproductive Cycle of Potomida littoralis (Cuvier, 1798) (Bivalvia: Unionidae) in Lake Gölbaşı, Turkey. Pakistan Journal of Zoology, 45(5):1311-1319.

Şereflişan, H., Şereflişan, M., Soylu, S. (2009). Description of glochidia of three species of freshwater mussels (Unionidae) from southeastern Turkey. Malacologia, 51: 165-173. [CrossRef]

Sereflisan, M., Şereflişan Hülya (2001). Kırıkhan Gölbası Gölü Hatay Balık Faunası. XI. Ulusal Su Ürünleri Sempozyumu 04-06 Eylül 2001 Hatay.

Thomas, G.R., Taylor, J., Leaniz, C.G. (2010). Captive breeding of the endangered freshwater pearl mussel Margaritifera margaritifera. Endangered Species Research, 12: 1-9. [CrossRef]

Treasure, J.W., Turnbull, T. (2000). The pathology and seawater performance of farmed Atlantic salmon infected with glochidia of Margaritifera margaritifera. Journal of Fish Biology, 57: 858-866. [CrossRef]

Treasurer, J.W., Hastie, L.C., Hunter, D., Duncan F., Treasurer, C.M. (2006). Effects of (Margaritifera margaritifera) glochidial infection on performance of tank-reared Atlantic salmon (Salmo salar). Aquaculture, 256: 74-79. [CrossRef]

von Proschwitz, T. (1999). Art Databanken 2015-12-02. Faktablad: Unio crassus - tjockskalig målarmussla. - ArtDatabanken, SLU 2015.

Wachtler, K., Dreher-Mansur M.C., Richter, T. (2001). Larval types and early postlarval biology in naiads (Unionoida). In Ecology and evolution of the freshwater mussels Unionoida (pp. 93-125). Springer, Berlin, Heidelberg. [CrossRef]

Waller, D.L., Mitchell, L.G. (1989). Gill tissue reactions in walleye Stizostedion vitreum vitreum and common carp Cyprinus carpio to glochidia of the freshwater mussel Lampsilis radiata siliquoidea. Diseases of Aquatic Organisms, 6: 81-87. [CrossRef]

Wen, H.B., Jin, W., Ma, X.Y., Zheng, B.Q., Xu, P., Xu, L., Gu, R.B. (2018). Vitro culture of axe-head glochidia in pink heelsplitter Potamilus alatus and mechanism of its high host specialists. Plos One, 13: 1-19. [CrossRef]

Zieritz, A., Gum, B., Kuehn, R., Geist, J. (2012). Identifying freshwater mussels (Unionoida) and parasitic glochidia larvae from host fish gills: a molecular key to the North and Central European species. Ecology and Evolution, 2: 740-750. [CrossRef]

Ziuganov, V.V., Nezlin, L.P. (1988). Evolutionary aspects of the symbiosis of pearl mussels and salmonid fishes. The problems of macroevolution (pp. 110-111), Nauka, Moscow. 